\title{
The Effects of The Interest Rate Volatility on Turkish Money Demand
}

\author{
Yıldız SAĞLAM ÇELIKÖZ (Corresponding author) \\ Economics Departmant, Mustafa Kemal University \\ Tayfur Sökmen Kampüsü; Serinyol/Turkey
}

Tel: 90-326-245-5845(1239) E-mail: yildizsaglam@yahoo.com

\author{
Ünal ARSLAN \\ Economics Departmant, Mustafa Kemal University \\ Tayfur Sökmen Kampüsü; Serinyol/Turkey \\ Tel: 90-326-245-5845(1252) E-mail: uarslan@politics.ankara.edu.tr
}

Received: December 16, 2010

Accepted: May 11, 2011

doi:10.5539/ibr.v4n4p286

\begin{abstract}
This study aims to examine, especially the effects of interest rate (time deposit and treasury bills) volatilities on the demand for money in case of Turkey for 1987: 1-2007: 3 period. Quarterly data of all variables are used as the research data and Pesaran, Shin and Smith (2001) 's bound test is used as the research method. In computing interest rate volatilities, moving-sample standart deviation method which is proposed by Kenen and Rodrik (1986) and Koray and Lastrapes (1989) is used. According to the results, the long run coefficient of gross domestic product is positive and statistically significant as expected. Although, the volatility of interest rate on treasury bills is positive as expected, it is statistically insignificant. On the other side, the coefficient of volatility of interest rate on time deposit, the coefficient of inflation rate and the coefficient of exchange rate are all negative and statistically significant as expected.
\end{abstract}

Keywords: Money Demand, Bound Test, Interest Rate Volatility

\section{Introduction}

Examining the determinant of the demand for money is important in order to create and conduct a healthy monetary policy which is closely related to whole economy. For example, a factor that increases the demand for money may adversely affect economic performance by increasing nominal income and velocity of money circulation.

This study aims to examine, especially the effects of interest rate volatilities in case of Turkey along with traditional factors affecting the demand for money. Since the increase in interest rate volatility is expected to lead structural changes in the structure of behavioral relations which defines financial sector (Walsh, 1984: 133) it will also greatly affect the demand for money. But, it must be stressed here that the nominal interest rate includes two components: Expected real rate of return and an expected rate of inflation. Since nominal interest rate volatility may reflect the volatility of either one or both of these components, it can be said that the impact of interest rate volatility could have emerged in two-ways. Although, there is a consensus among economists that the volatility of real interest rate increases money demand, the effect of the volatility of inflation is arguable. But, empirical evidences indicate that there is a negative relationship between volatility of inflation and the demand for money. The justification: an increase in the volatility of inflation makes all nominal assets including money riskier to hold since their value in terms of goods and services becomes unpredictable. The greater risk will cause some investors to shift part of their wealth out of nominal assets into tangible assets such as commodity inventories. Therefore, to the extent that volatility of nominal interest rate reflects volatility of inflation, volatility of nominal interest rates could have a negative effect on money demand (Garner, 1986; 30-31). While the theoretical perspectives reveal multifaceted effects, issues relating to empirical studies have revealed conflicting findings.

In this study, firstly we explained the theoretical approaches to the effects of the interest rate volatility on the demand for Money. Secondly we compiled the empirical studies examining relationship between interest rate volatility and the demand for money on the basis of countries. Then, the fourth section includes methodology. Under this section we used subsection in order to explain the variables that are used in money demand model and the empirical model that we used in analyzing Turkish money demand and the results of our analysis. In the conclusion section, we explained and discussed our findings about the Turkish money demand and the interest rate volatilities. 


\section{Theoretical Approaches to the Effects of the Interest Rate Volatility}

Theoretical arguments noted that in determining the level of demand for real balances, not just the interest rate level but also interest rate volatility must be adressed as an important variable (Falls and Zangeneh, 1989: 27). Different relationship (negative or positive) between the demand for money and interest rate volatility have been advocated by different theories (Choudhry, 1999: 622). According to portfolio theories of the demand for money, high interest rate volatility will increase the demand for money. Money is a desirable asset in financial portfolios, although it pays less interest than other assets. Because, when interest rates fluctuate the value of money does not change while the value of bonds change. This makes money less risky than others. On the other side, the transaction demand for money also rises when interest rate volatility increases. Because, an increase in the interest rate volatility will rise the risk of holding alternative assets of money. In such circumstance firms and households desire large risk free cash balances (Garner, 1986, 29-30). Hence, it can be said that there is a positive relationship between money demand and interest rate volatility. On the other side, Longstaff and Schwartz (1993: 70) argued that there is a negative relationship between bond yields and interest rate volatility. It means that an increase in the interest rate volatility which is related to interest rate fluctuations will lead to a decrease in bond yields. A reduction in bond yields causes individuals to demand more money. This situation verifies that there is a positive relationship between the volatility of interest rate on bonds and money demand.

On the other side, Falls and Zangeneh (1989: 27) and Walsh (1984: 148) emphasized the effect of the interest rate volatility on income and interest rate elasticities of the demand for real balances. Falls and Zangeneh (1989: 27) asserted that when interest rate is stochastic in Baumol-Tobin inventory model, interest rate and income elasticities of the demand for money will be the functions of interest rate's volatility. That is the volatility in the interest rate which is measured by its variance would lead to a change in elasticities of the demand for real balances.

Based on Tobin (1958)'s study which claims the demand for risky assets depends upon the joint probability distribution of asset returns and in a mean-variance framework, the demand for an asset is a function of both the expected rates of return on all assets and the covariances among asset returns, Walsh (1984:134) argued that if the monetary authority changes the way in which it adjusts the money supply in response to shocks to the economy, the covariances between the returns on other assets will be affected. This will produce a shift in asset demand equations in general and in the money demand function in particular. The policy-induced change in the demand for money function is not simply a change in the intercept; interest and income elasticities also change. By using a conventional rational expectation model he concluded that when there is a change in monetary policy, there will be shifts in the interest and income elasticities of the demand for money, since the behaviour of the price of bonds is dependent upon the monetary authority's actions.

\section{Empirical Studies About the Effects of The Interest Rate Volatility}

Baba, Hendry and Starr (1992), under the assumption of the lack of capital market, examined the relationship between real M1 and real Gross National Product (GNP), bond / treasury bill yield spread, one-month treasury bill rate, inflation rate, deposit rate and expected risk of holding long term debt which is calculated as the moving standard deviation of the long-term bond yields by using the cointegration method. At the end of this study that includes 1960 (3)-1988 (3) period, it is concluded that the risk within the cointegration vector is positively related with real money demand. Choudhry (1999), estimated the money demand equation for the post second World War (1954-1996) period by using quarterly real M1 series, real GNP, three-month treasury bill interest rate as short-term interest rate, long-term government bond interest rate as long-term interest rate and the volatilities of these interest rates. In this study, firstly, the cointegration between, real M1, real income, short-term interest rate and short-term interest rate volatility is examined. Then, the estimation is made by using long-term interest rate instead of short-term interest rate and long-term interest rate volatility instead of short-term interest rate volatility. Results indicate that only the long-term interest rate volatility has a significant and positive effect on real M1 demand while short-term interest rate volatility has a significant and negative effect on real M1 demand. On the other side, Garner (1986) estimated M1 demand equations with quarterly data by dividing the sample period into two subperiods: 1959:Q3-1973:Q4 and 1976:Q1-1984:Q1. As a result, he found that interest rate volatility has a negative and statistically significant coefficient in the first subperiod while it has a positive but statistically insignificant coefficient in the second subperiod.

Payne (1992) examined the relationship between real M1 and interest rate volatility of three-month Treasury bill rate for both pre- and post-1979 periods by using two alternative methods in measurement of interest rate volatility. The first measures are -a four- and eight-quarter moving standard deviation of actual interest rate $\left(\sigma_{i}\right)$. The second measure is the moving standard deviation of unanticipated interest rate $\left(\sigma_{\mathrm{i}}-\mathrm{E}_{\mathrm{i}} \sigma_{\mathrm{i}}\right)$. In estimations which are made by four-quarter moving standard deviation, actual interest rate volatility and unanticipated interest rate volatility are negative but statistically insignificant for both periods. The estimations which are made by eight-quarter moving standard deviation the results yield statistically insignificant interest rate volatility for pre-1979 period. On the other 
side, actual interest rate volatility is positive and statistically significant at the 5 percent while unanticipated interest rate volatility is statistically insignificant for post -1979 period. As a whole, according to this study the interest rate volatility does not affect the demand for money in a meaningful way.

Falls and Zangeneh (1989), in order to examine the effects of interest rate volatility on demand of real M1 and real M2, used an interaction term $\left(\mathrm{IR}_{t}\right)$ which includes the product of three-month U.S. treasury bill interest rate $\left(\mathrm{r}_{t}\right)$ and interest rate variance $\left(\mathrm{V}_{\mathrm{t}}\right)$. On the other side the sample period 1959: 1-1979: 3 is divided into two sub-samples as 1959: 1-1972: 3 the interest rate targeting period and 1972: 4-1979: 3 period in which Federal Reserve System target monetary aggregates. By this study, they tested the hypothesis of Walsh (1984) who claimed that an increase (decrease) in interest rate volatility will decrease (increase) the interest rate and income elasticity of money demand. But the evidence does not support the hypothesis for both real M1 and real M2. (Note 1)

Sağlam (2005), examined the relationship between reel money demand and reel GDP, the volatility of interest rate on time deposits, the volatility of interest rate on treasury bills, exchange rate and inflation rate for Turkey during 1987:1-2005:1 period by using Johansen (1988) and Johansen and Juselius (1990) contegration method. In computing the volatilities moving-sample standart deviation method is used. At the end of this study it is concluded that volatility of interest rate on time deposits effect the demand for money negatively while volatility of interest rate on treasury bills effects the demand for money positively.

Despite the empirical findings about the effects of volatility on money demand appear contradictory, it is clear that interest rate volatility effects money demand function. In this context, our study aims to examine possible effects of interest rate volatilities on Turkish money demand for 1987: 1-2007: 3 period.

\section{Methodology}

In this section we explain the variables that are used in money demand function seperately. Then we construct the empirical model and examine the relationship between real monetary aggregate $\mathrm{M} 2 \mathrm{Y}$ as money demand and real gross domestic product (GDP), volatility of interest rate on treasury bills (RBSH), volatility of interest rate on time deposit (RMSH), exchange rate (EXCH) and inflation rate (INF).

\subsection{Variables Used in Money Demand Model}

Monetary aggregates are used as the dependent variable in empirical studies while scale variable which is taken as income (Gross Domestic Product, Gross National Product, Net National Product or permanent income) and opportunity cost of holding money which could be interest rate, inflation rate or exchange rate are all used as independent variables.

\subsubsection{Dependent Variable: Monetary Aggregates}

Since there is no data related to the amount of demand for money, money supply or monetary aggregates data are used in empirical research in order to represent the demand for money by moving from the assumption that the money market is in equilibrium (Keyder 2002: 341). However, there is no consensus among economists about the definition of money supply or monetary aggregates. Some researchers defined the money as the aggregate of demand deposits and time deposits while the classical view which emphasize the function of the medium of exchange define the money as the aggregate of demand deposits and currency in circulation. On the other side, Gurley and Shaw (1955) who emphasize the liquidity property of money, advocated that liquid financial assets that are held in the economy as a whole are money (Olgun 1982: 91). Today, there is a wide spectrum of assets which change according to the liquidity and acceptability. In this sense, the traditional monetary aggregates are defined as $M 0, M 1, M 2, M 3, M 4$ and $M 5$ (Lewis and Mizen, 2000: 263-265). But it must be emphasized here that, even if the definitions of monetary aggregates vary across countries according to institutional characteristics and financial structures, money stocks are usually divided into two main groups, such as the narrow and broad money. Narrow money consists of assets which are readily available and transferable in every day transactions and provide the means-of-exchange function while broad money comprises of a wide range of assets rendering portfolio opportunity to asset holders (Sriram 1999(a): 18).

Even though monetary definitions described above are nominal, the demand for money is a demand for real balances. In order to get the real money measurement from the nominal value of money, nominal balances should be divided by an appropriate price index (Laidler 1993: 98). Several different indexes can be used for this purpose. In the first option, a basket measure of the price level such as consumer price index (CPI) and wholesale price index (WPI) can be used. In the second option, price deflators are used for gross domestic product (GDP) or total final expenditure (TFE) (Lewis and Mizen, 2000: 265). (Note 2)

\subsubsection{Scale Variable}

In estimation of the demand for money, the scale variable is used as a measure of transactions which are related to economic activities. Scale variable is usually represented by variables which express, income, expenditure or wealth concept (Sriram, 2001: 336). 
The level of income is often used as a proxy for the volume of transactions in an economy. Especially, it has played an important role in empirical tests of transactions-based theories of the demand for money. Since gross national product series, net national product series and gross domestic product series move rather closely together over time, no important difference in results is obtained by using one or the other, in measuring income variable (Laidler 1993: 98-99). On the other side the per capita values of these series can also be used as income variable. In the case of using per capita data, the per capita value of the demand for money (dependent variable) must be included in the function. It means that both income and the demand for money (money supply) must be divided by the population. When a nominal money demand function is estimated, income and money supply variables must be given by current price, while in real money demand function estimates, income and money supply variables must be deflated by a relevant price index. Relevant deflator may be a price index such as GNP or GDP deflator (Keyder 2002: 343).

Wealth is another important choice to represesnt the scale variable (Sriram 1999(a): 22). Wealth variable can be used as the upper limit of the money which is available. Especially, in approaches which emphasize the motivation of wealth, it would be better using wealth as a scale variable. But, although this view has been adopted since Pigou, income is often used in empirical tests. The reason for this is the difficulties in measuring "wealth" (Keyder 2002: 343).

However, it has recently been argued that the use of GNP as a scale variable has potential problems. Judd and Scadding (1982: 1009), listed the problems of using GNP as: 1) Transfers and transactions in financial assets and existing goods are neglected in GNP. 2) GNP includes imputations that may involve no transactions. 3) GNP nets out intermediate transactions. Sriram (1999(a): 21) asserted that because of these problems, some other measures like bank debits, bank loans and gross debits to demand deposits must also be employed.

On the other side, Bomberger and Makinen (1980) claimed that since gross national product, net national product and national income include exports of domestically produced goods and services and exclude the value of imported goods and services, the demand for money can be estimated in the best way by gross national expenditure which includes import and excludes export. In their estimations which are made by taking the 16 developed countries' gross national product and gross national expenditure data, they found that gross national expenditure variable gave the best result with $\mathrm{R}^{2}$ measure.

Mankiw and Summers (1986), argued that gross national product is only a proxy for total transactions, therefore, another variable may be a better proxy for estimating a money demand function. They compared velocity measured with respect to gross national product ( $\mathrm{Y} / \mathrm{M})$ to velocity measured with respect to nominal consumer expenditure (C/M) in order to test the stability of U.S. M1 and M2 velocity for period 1960:I-1984:IV using quarterly data. They concluded that velocity measured by using nominal consumer expenditure $(\mathrm{C} / \mathrm{M})$ is more stable than velocity measured by using gross national product $(\mathrm{Y} / \mathrm{M})$. On the other side, under restrictive assumptions which are unity quantity elasticity and zero interest elasticity, consumer expenditure appears the best scale variable in money demand function. For the same period, they compared the standart formulation in which real GNP is the scale variable and the GNP deflator is the price level to alternative formulation in which real consumer spending is the scale variable and the consumer expenditure deflator is the price level and they concluded that for both monetary aggregates (M1 and M2) consumer spending produces a smaller standart error estimates than GNP. Shortly, Mankiw and Summers (1986)'s empirical results indicated that consumption expenditure is a better scale variable than GNP in money demand function.

\subsubsection{Opportunity Cost of Holding Money}

The selection of the opportunity cost of holding money as a variable is one of the most important aspects of modeling the demand for money. The opportunity cost variable involves: 1) The own rate of return on money and 2) The rate of return on alternative assets to money (Sriram 1999 (b): 8). In general it is assumed that the own rate of return on money as an asset is zero. But time deposit explicitly bears interest and any variation in the rate of return it yields will effect the demand for money which is defined broadly while demand deposit which is included in narrow money definition bears no explicit interest (Laidler, 1993: 105). On the other side, the rate of return on alternative assets to money involves yields on domestic financial and real assets for a closed economy and additionally on foreign assets for an open economy (Sriram, 2001: 336).

The closed economy version of the money demand function includes only domestic financial and real assets. The returns on domestic financial assets are represented by the own rate of money and the return on the alternative assets for money. But the returns on real assets are represented by the expected rate of inflation (Sriram 1999 (a): 23-24). The reasons of taking the inflation rate as the opportunity cost of holding money in studies of money demand about underdeveloped and developing countries: 1) Underdeveloped countries are characterized by poorly developed financial markets, 2) The interest rate in underdeveloped countries usually has a ceiling imposed by the central bank, 3) Since the interest rate is the product of an inefficient/non-competitive financial system, it may not reflect underlying economic conditions, 4) Real assets such as land or property are likely to dominate an individual's portfolio choice 
(Carruth and Sánchez-Fung, 2000:1440). 5) There is a limited substitution possibility between money and other financial assets due to the under-developed financial markets outside the banking system, 6) The interest rates may show insufficient variation for a long period of time because they may be regulated by the government, 7) The payment of interest is legally prohibited in some countries, 8) Since the financial system is underdeveloped the interest rates may not be observable or interest rate data may not be available (Sriram, 1999 (a): 25).

The conventional theory of money demand which is based on a closed economy framework and assumed that the demand for money is determined by domestic interest rate as an opportunity cost variable is questionable. Because this assumption leads one to conclude that there is only a single currency in each country and that all domestic agents consider domestic assets to be the only substitute to money as a store of wealth. Since there is a globalization and rapid liberalization of financial markets in developing countries, the determination of money demand should also include the influences of open economy factors through foreign opportunity cost variables (Khalid, 1999: 1129).

"In an open economy, portfolio based money demand models, money is considered as part of portfolio, which consists of domestic financial and real assets and foreign assets" (Civcir, 2003: 518). Therefore, money demand in an open economy is determined by domestic income, foreign income, domestic interest rate, foreign interest rate and exchange rate depreciation. If the domestic currency is expected to depreciate more, both domestic and foreign residents will prefer to hold less domestic money and more foreign money. Thus, this case helps the substitution of foreign currency for domestic currency and is known as "currency substitution" effect. On the other side, as a result of the increase in the expected depreciation of domestic money, the relative attractiveness of foreign bonds according to domestic bonds would also increase. Therefore, when there is no complete restrictions on capital movements, both domestic and foreign residents will tend to increase their holding of foreign bonds while decreasing their holdings of domestic bonds. This case is called "capital mobility" effect (Khalid, 1999: 1130).

\subsection{Empirical Model}

In this study we examine the effects of interest rate volatilities on real monetary aggregate M2Y as money demand. Naturally, the dependent variable is M2Y and real gross domestic product (GDP), volatility of interest rate on treasury bills (RBSH), volatility of interest rate on time deposit (RMSH), Inflation Rate (INF) and Exchange Rate (EXCH) are independent variables. We used the log-linear money demand function on the basis of log-linear money demand functions that are used by Bjørnland (2005), Carruth and Sanchez-Fung (2000) and Civcir (2003).

$$
\left(m^{d}-p\right)_{t}=\beta_{0}+\beta_{1} y_{t}+\beta_{2} r m_{t}+\beta_{3} r b_{t}+\beta_{4} e_{t}+\beta_{5} \Delta p_{t}
$$

This function indicates that the real money demand $\left(m^{d}-p\right)_{t}$ depends on real income $\left(y_{t}\right)$, own rate of money $\left(r m_{t}\right)$, opportunity cost of holding money $\left(r b_{t}\right)$ which is the rate of return on alternative assets to money, exchange rate $\left(\Delta e_{t}\right)$ and inflation rate $\left(\Delta p_{t}\right)$.

All variables are in logarithm except the interest rates. Log-linear form, indicates that the coefficients of the logarithmic variables can be interpreted as the long-run elasticities while the coefficients which are not expressed in logarithmic forms (interest rates) can be interpreted as the semi-elasticities (Mutluer and Barlas, 2002: 61).

The scale variable indicates that in general real income is positively related to real money demand. The coefficient on the interest rate on domestic money (in other words the interest rate on time deposits) is expected to be positive when interest bearing deposits (time deposits or term deposits) are included in broad money while the interest rate on treasury bills is expected to be negative indicating an alternetive return of money. On the other side, since rising inflation induces agents to hold real domestic assets instead of money, the inflation rate is expected to affect demand for money negatively. Finally, the foreign exchange rate measures the rate of return on holding foreign currency. Therefore an increse in the exchange rate implies that the domestic money is depreciated and the expected return from holding foreign money increases. It can be said that the sign of exchange rate is negative, since depreciating in domestic currency, causes agents to substitute foreign currency instead of domestic currency (Bjørnland, 2005: 377 and Mutluer and Barlas, 2002: 67).

\subsubsection{Data Set and Empirical Findings}

Except the treasury bill rate, all the data have been obtained from the Central Bank of the Republic of Turkey, Electronic Data Delivery System. 1987:1-1994:2 period for treasury bill is taken from International Financial Statistics (18660C.ZF series) and the rest of the data of this variable is calculated from auctions of treasury bills which is taken from Central Bank of the Republic of Turkey, Market data. The study examines the effects of the interest rate volatilities on Turkish money demand function for the period between 1987: 1-2007: 3. The basic properties of the series can be explained as follows: Turkish broad money (M2Y), composed of narrow money M1 (currency in circulation plus demand deposits) plus time deposits in domestic currency plus deposits denominated by foreign currencies. It is used here as the monetary aggregates and deflated $(1987=100)$ by using the wholesale price index (WPI) in order to obtain real M2Y as real money demand. The scale variable that used in the analysis is gross domestic 
product (GDP) and it is deflated by wholesale price index in order to obtain real gross domestic product or real income. The exchange rate is nominal exchange rate $(\mathrm{EXCH})$ which is Turkish liras corresponding to 1 USA dolar. The inflation rate (INF) is calculated as the change in whole price index $\Delta p=p_{t}-p_{t-1}$. Instead of the interest rate on treasury bills, the volatility of the interest rate on treasury bills (RBSH) and instead of the interest rate on time deposits, the volatility of the interest rate on time deposits (RMSH) are used. The volatility method which is used here is suggested by both Kenen and Rodrik (1986) and Koray and Lastrapes (1989) and it is used by Arize (1998) to measure the exchange rate volatility for USA. It is constructed by the moving-sample standard deviation as expressed (Arize, 1998: 33):

$$
J_{t+m}=\left[\frac{1}{m} \sum_{i=1}^{n}\left(R M_{t+i-1}-R M_{t+i-2}\right)^{2}\right]^{1 / 2}
$$

But in this study $m$ which denotes the order of the moving average is $4 \quad(m=4)$

\subsubsection{Unit Root Test}

The stationarity of the time series which are used in econometric studies is important. Using non-stationary series may create econometric problems such as may lead to misleading results. If two series are not stationary, the regression which is created by these series are called spurious regression by Granger and Newbold (1974). Even if there is not a significant relationship between the two series, a high $\mathrm{R}^{2}$ will result in regression and t-statistics are significant, but the results will not carry any_economic sense. The reason for the spurious regression is the stocastic trend that the time series have or the strong tendency (Lewis and Mizen, 2000: 291 and Gujarati, 1999: 725).

The most common method that is used in testing the stationarity of the time series is the unit root test. By examining the existence of unit root in time series, it is decided whether the series are stationary or not. If the series do not include unit root, they are stationary, but if they include a unit root they are non-stationary. However there are different types of unit root test the most common one is Augmented Dickey Fuller (ADF) unit root test. This test is developed by Dickey-Fuller. The regression which is used for ADF test is as given below (Gujarati, 1999: 718-720):

$$
\Delta Y_{t}=\beta_{1}+\beta_{2} t+\delta Y_{t-1}+\alpha_{i} \sum_{i=1}^{k} \Delta Y_{t-i}+u_{t}
$$

In equation (4.3), $\Delta$ indicates the term of lagged difference, $t$ is trend variable, $k$ is the lag number which provides white noise error. $u_{t}$ is a stochastic error term which has a zero mean, a constant variance and no serial correlation (Gujarati, 1999:720).

In this study, the stationarity of each variable is tested by using the Augmented Dickey Fuller (ADF) unit root test. Firstly, this test is applied to the level of variables and then to their first differences. The null hypothesis tested is that the variable under investigation has a unit root against the alternative that it does not.

Table.1 indicates the ADF unit root test results derived from the series that are used in the study. Based on the results, the the null hypothesis of unit root is rejected at $\% 1$ and $\% 5$ significance levels according to model I for M2Y, GDP and RBSH while it is accepted for INF and EXCH variables at the same significance levels. On the other side, the null hypothesis is accepted at \%1 significance level according to model I and II for RMSH, while it is rejected at $\% 5$ significance level according to model I and II, but it is accepted at both significance levels according to model III. The null hypothesis is accepted according to model II and III for M2Y, GDP and EXCH variables while it is again rejected for RBSH according to the both models. It is rejected only for INF according to model III. As it can be seen all variables are not stationary at the same level. Therefore we can't use Engle and Granger (1987) cointegration or Johansen (1988) and Johansen and Juselius (1990) cointegration method. Because both of methods are required the time series to be stationary in level or in first difference. In this situation we can apply bound test which is developed by Pesaran, Shin and Smith (2001).

\subsubsection{Cointegration}

This test is a new approach to test the relationship between variables in levels, regardless of whether they are purely I (0), purely I (1) or mutually cointegrated. The test statistic is the familiar Wald or F-statistic in a generalized Dickey-Fuller type regression which is used in testing the significance of lagged levels of the variables under consideration in a conditional unrestricted equilibrium correction model (ECM) (Pesaran, Shin and Smith, 2001: 289-290). 


$$
\begin{gathered}
\Delta \ln M 2 Y=a_{0}+\sum_{i=1}^{m} a_{1 i} \Delta \ln M 2 Y_{t-i}+\sum_{i=0}^{m} a_{2 i} \Delta \ln G D P_{t-i}+\sum_{i=0}^{m} a_{3 i} \Delta R B S H_{t-i}+\sum_{i=0}^{m} a_{4 i} \Delta R M S H_{t-i} \\
+\sum_{i=0}^{m} a_{5 i} \Delta \ln I N F_{t-i}+\sum_{i=0}^{m} a_{6 i} \Delta E X C H_{t-i}+a_{7} \ln M 2 Y_{t-1}+a_{8} \ln G D P_{t-1}+a_{9} R B S H_{t-1} \\
+a_{10} R M S H_{t-1}+a_{11} \ln I N F_{t-1}+a_{12} E X C H_{t-1}+u_{t}
\end{gathered}
$$

The cointegration can be tested by $H_{0}: a_{7}=a_{8}=a_{9}=a_{10}=a_{11}=a_{12}=0$ hypothesis.

"It is shown that the asymptotic distributions of both statistics are non-standard under the null hypothesis that there exists no relationship in levels between the included variables, irrespective of whether the regressors are purely I (0), purely I (1) or mutually cointegrated. We establish that the proposed test is consistent and derive its asymptotic distribution under the null and suitably defined local alternatives, again for a set of regressors which are a mixture of I (0) / I (1) variables. Two sets of asymptotic critical values are provided for the two polar cases which assume that all the regressors are, on the one hand, purely I (1) and, on the other, purely I (0). Since these two sets of critical values provide critical value bounds for all classifications of the regressors into purely I (1), purely I (0) or mutually cointegrated, we propose a bounds testing procedure. If the computed Wald or F-statistic falls outside the critical value bounds, a conclusive inference can be drawn without needing to know the integration/cointegration status of the underlying regressors. However, if the Wald or F-statistic falls inside these bounds, inference is inconclusive and knowledge of the order of the integration of the underlying variables is required before conclusive inferences can be made" (Pesaran, Shin and Smith, 2001: 290).

In order to apply the bound test first of all we must determine the lag number which is labeled as " $m$ " in the equation (4.4). The lag number is determined as 1 according to Sequential Modified LR test statistic (LR), Final Prediction Error (FPE), Akaike Information Criterion (AIC), Schwarz Information Criterion (SC) and Hannan-Quinn Information Criterion.

Tablo 2 includes the F-statistics value which are calculated to test $H_{0}: a_{7}=a_{8}=a_{9}=a_{10}=a_{11}=a_{12}=0$ hypothesis after estimation of (4.4) equation by 1 lag and critical values which are taken from Pesaran, Shin and Smith (2001). These critical values are valid for 5 independent variables at $\% 5$ significance level. In table 2 it can be seen that the calculated F-statistic is higher than the upper bound. This means that there is a cointegration relationship between 6 variables.

\subsubsection{Long-Run Relationship}

The long-run relationship between variables are examined by Autoregressive Disributed Lag (ARDL) model. The ARDL model is as follows:

$$
\begin{aligned}
\ln M 2 Y_{t}=a_{0}+\sum_{i=1}^{m} & a_{1 i} \ln M 2 Y_{t-i}+\sum_{i=0}^{m} a_{2 i} \ln G D P_{t-i}+\sum_{i=0}^{m} a_{3 i} R B S H_{t-i} \\
& +\sum_{i=0}^{m} a_{4 i} R M S H_{t-i}+\sum_{i=0}^{m} a_{5 i} \ln I N F_{t-i}+\sum_{i=0}^{m} a_{6 i} \ln E X C H_{t-i}
\end{aligned}
$$

The lag length in ADRL model is still determined by using AIC. This process is made by a method proposed for determining the lag length in Kamas and Joyce (1993) 's analysis of causality. Within this method's framework, the lag number is determined according to AIC. In our study, the maximum lag number is taken 12 and it is concluded that equation (4.5) must be estimated by 2 lags for M2Y, 0 lag for GDP, 1 lag for RBSH, 1 lag for RMSH, 2 lags for INF and 2 lags for EXCH. (Note 3)

Tablo 3 indicates the estimation results of ADRL $\left(\begin{array}{lllll}2 & 0 & 1 & 1 & 2\end{array}\right)$ model. On the other side, we calculated the long-run coefficient according to results by dividing the coefficients of the lagged independent variables by the correction term. Correction term can be obtained by 1 minus the short-run coefficient of the independent variable (Gujarati, 1999: 608). (Note 4)

According to results, there is a statistically significant relationship between M2Y and GDP and the sign of the GDP coefficient is positive as expected. This result indicates that income effects the money demand positively as it is argued theoretically that when income increases the demand for money increases or vice versa. On the other side, the interest rate on treasury bills effects the demand for money negatively, since high interest rate causes individuals to demand less money and more treasury bills which is the alternative of money. But when the volatility of the interest 
rate on treasury bills increases the individulas will demand more money, since the volatility includes some risk. According to our results there is no statistically significant relationship between M2Y and RBSH although the coefficient of RBSH is positive as theoretically expected. The coefficient of RMSH is negative and statistically significant as expected. This result indicates that volatility of interest rate on time deposits leads individulas to avoid demanding money, despite interest rate on time deposits encourages individuals to demand more money. The relationship between M2Y and INF is statistically significant and the sign of the coefficient is negative. This result indicates that since there is a limited substitution possibility between money and other financial assets outside the banking system, individuals substitute real assets instead of alternative assets to money in Turkey. The relationship between M2Y and EXCH is statistically significant and negative. This circumstance indicates that there is a currency substitution in Turkey.

4.2.4. Short-Run Relationship

$$
\begin{aligned}
\Delta \ln M 2 Y_{t}=a_{0}+a_{1} E C_{t-1} & +\sum_{i=1}^{m} a_{2 i} \Delta \ln M 2 Y_{t-i}+\sum_{i=0}^{m} a_{3 i} \Delta \ln G D P_{t-i}+\sum_{i=0}^{m} a_{4 i} \Delta R B S H_{t-i} \\
& +\sum_{i=0}^{m} a_{5 i} \Delta R M S H_{t-i}+\sum_{i=0}^{m} a_{6 i} \ln \Delta I N F_{t-i}+\sum_{i=0}^{m} a_{7 i} \ln \Delta E X C H_{t-i}+\mu_{t}
\end{aligned}
$$

The $\mathrm{ECT}_{-1}$ variable is the one lagged value of the error terms series which are derived from the long-run relationship. The coefficient of this variable indicates how much of short-run imbalance will correct in the long-run. The coefficient is expected to be negative.

In our study, the lag number of variables that take place in equation (4.6) is determined by AIC and methods that used in investigating the long-run relationship. According to maximum lag number that is chosen as 12 , it is concluded that short run relationship must be investigated by $\operatorname{ARDL}(2,0,1,1,2,2)$ model.

Table 4, indicates the results of Error Correction Model based on ARDL model. The Error Correction Term has a negative sign as expected, and it is statistically significance. On the other side, in the short term, there is a positive and but not statistically significant relationship between $\mathrm{M}_{2} \mathrm{Y}_{-1}$ and $\mathrm{GDP}_{\mathrm{t}}$. Similarly, a negative and statistically significant relationship was found as expected between M2Y and the current value of inflation. However, there is a negative relation relationship between $\mathrm{M} 2 \mathrm{Y}$ and the interest rate volatility of time deposit but it is statistically insignificant.

\section{Conclusion}

In this study we examined, especially the effects of interest rate (time deposits and treasury bill) volatilities on money demand in the case of Turkey for 1987: 1-2007: 3 period. We used quarterly data of all variables and Pesaran, Shin and Smith (2001) bound test. In computing interest rate volatility, moving-sample standart deviation method which is proposed by Kenen and Rodrik (1986) and Koray and Lastrapes (1989) is used. According to the results, the coefficient of the real gross domestic product is positive and statistically significant as expected. There is statistically insignificant relationship between money demand and the volatility of the interest rate on treasury bills although the sign of the coefficient is positive as theoretically expected. Similarly, the coefficients of the inflation rate and nominal exchange rate are negative and statistically significant as expected. These results indicates that inflation and exchange rate effects the demand for money negatively. However, a statistically significant relationship is found between Turkish money demand and the volatility of the interest rate on time deposits.

Positive and statistically significant coefficient of real gross domestic product indicates that when the income of indivuduals increses in Turkey, they demand more money, while negative and statistically significant coefficient of the volatility of the interest rate on time deposits indicates that when the there is a volatility in the interest rate of time deposits, individuals will demand less domestic currency. The volatility of interest on treasury bills causes individuals to demand more money, but the result is not statistically significant in Turkey. The negative and significance coefficients of inflation rate indicates that the Turkish people hold real domestic assets instead of money in inflationary periods. On the other side the negative and significance exchange rate coefficient indicates that when exchange rate increases, the expected return from holding foreign money increases, too. So Turkish people substitute foreign currency instead of domestic currency and this causes the demand for money to decrrease.

\section{References}

Arize, A.C. (1998). The Effects of Exchange Rate Volatility on U.S. Imports: An Empirical Investigation, International Economic Journal 12 (3): 31-40, doi:10.1080/10168739800080020, http://dx.doi.org//10.1080/10168739800080020 
Baba Yoshihisa, Hendry D.F. \& Starr, R.M. (1992). The Demand for M1 in the U.S.A., 1960-1988, Review of Economic Studies 59 (198) : 25-61.

Bjørnland Hilde C. (2005). A Stable Demand for Money Despite Financial Crisis: The Case of Venezuela, Applied Economics 37 : 375-385, doi:10.1080/00036840412331315015, http://dx.doi.org//10.1080/00036840412331315015

Bomberger W. A. \& Makinen, G. E. (1980). Money Demand in Open Economies: Alternative Specifications, Southern Economic Journal 47 (1: 30-39, doi:10.2307/1057058, http://dx.doi.org//10.2307/1057058

Carruth Alan \& Sánchez-Fung, J. R. (2000). Money Demand in the Dominician Rebuplic, Applied Economics 32 : 1439-1449, doi:10.1080/00036840050151511, http://dx.doi.org//10.1080/00036840050151511

Central Bank of the Republic of Turkey (CBRT), Electronic Data Delivery System. [Online] Available: http://evds.tcmb.gov.tr/yeni/cbt-uk.html

Central Bank of the Republic of Turkey (CBRT), [Online] Available: http://www.tcmb.gov.tr/

Civcir, İrfan. (2003). Money Demand, Financial Liberalization and Currency Substitution in Turkey, The Journal of

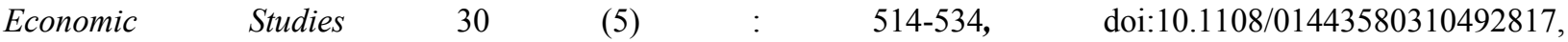
http://dx.doi.org//10.1108/01443580310492817

Choudhry Taufiq. (1999). Does Interest Ratte Volatility Affect The US M1 Demand Function? Evidence From Cointegration, The Manchester School 67 (6): 621-648, doi:10.1111/1467-9957.00172, http://dx.doi.org//10.1111/1467-9957.00172

Engle R. F., \& Granger C. W. J. (1987). Cointegration and error correction: Representation, estimation, and testing Econometrica $55: 251-276$, doi:10.2307/1913236, http://dx.doi.org//10.2307/1913236

Falls Gregory, A. \& Zangeneh, H. (1989). The Interest Rate Volatility and The Demand For Money: The Empirical Evidence, Quarterly Journal of Business and Economics $28: 26-42$.

Garner, Alan C. (1986). Does Interest RateVolatility Affect Money Demand?, EconomicReview January : 25-37.

Granger Clive W. J. \& Newbold, P. (1974). Spurious Regressions in Econometrics, Journal of Econometrics 2 (2) : 111-20, doi:10.1016/0304-4076(74)90034-7, http://dx.doi.org//10.1016/0304-4076(74)90034-7

Gujarati, Damodor, N. (1999). Temel Ekonometri (Çev. Ümit Şenesen ve Gülay Günlük Şenesen), (Birinci Basım), İstanbul: Literatür Yayınları:33, Literatür: Yayıncılık, Dağıtım, Pazarlama San. Ve Tic. Ltd. Şti.

Gurley John, G. \& Shaw, E. S. (1955). Financial Aspects of Economic Development, American Economic Review XLV : 515-38.

Johansen, Soren. (1988). Statistical analysis of cointegration vectors, Journal of Economic Dynamics and Control 12 : 231-54, doi:10.1016/0165-1889(88)90041-3, http://dx.doi.org//10.1016/0165-1889(88)90041-3

Johansen, S. \& Juselius, K. (1990). Maximum likelihood estimation and inference on cointegration- with applications to the demand for Money, Oxford Bulletin of Economics and Statistics $52: 169-210$,

doi:10.1111/j.1468-0084.1990.mp52002003.x, http://dx.doi.org//10.1111/j.1468-0084.1990.mp52002003.x

Judd John P. \& Scadding, J. L. (1982). The Search for a Stable Money Demand Function: A Survey of the Post-1973 Literature, Journal of Economic Literature 20 (3) : 993-1023.

Kamas, L. \& Joyce, J.P. (1993). Money, Income and Prices under Fixed Exchange Rates: Evidence from Causality Tests and VARs. Journal of Macroeconomics 15 (4) : 747-768, doi:10.1016/S0164-0704(05)80008-4, http://dx.doi.org//10.1016/S0164-0704(05)80008-4

Kenen, Peter B. \& Rodrik, D. (1986). Measuring and Analyzing the Effects of Short-term Volatility in Real Exchange Rates, The Review of Economics and Statistics 311-315. doi: 10.2307/1925511, http://dx.doi.org//10.2307/1925511

Keyder, Nur, (2002). Para Teori-Politika-Uygulama, Geliştirilmiş 8. baskı, Ankara: Bizim Büro Basımevi.

Khalid Ahmed K. (1999). Modelling Money Demand in Open Economies: The Case of Selected Asian Countries, Applied Economics 31 : 1129-1135, doi:10.1080/000368499323616, http://dx.doi.org//10.1080/000368499323616

Koray, F. \& Lastrapes, W. D. (1989). Real Exchange Rate Volatility and U.S. Bilateral Trade: A VAR Approach, The Review of Economics and Statistics 708-712, doi:10.2307/1928117, http://dx.doi.org//10.2307/1928117

Laidler, David. (1993). The Demand for Money-Theories, Evidence and Problems, Fourth Edition, The United States of America: HarperCollins College Publishers. 
Lewis, K. M. \& Mizen P. D. (2000). Monetary Economics (First Published), Newyork: Oxford University Pres, Great Clarendon Street, Oxford ox2 6DP.

Longstaff A. F. \& Schwartz, E. S. (1993). Interest Rate Volatility and Bond Prices, Financial Analysts Journal July-August : 70-74, doi:10.2469/faj.v49.n4.70, http://dx.doi.org//10.2469/faj.v49.n4.70

Mankiw N.G. \& Summers L. H. (1986). Money Demand and The Effects of Fiscal Policies, Journal of Money, Credit and Banking 18 (4) : 415-429, doi: 10.2307/1992462, http://dx.doi.org//10.2307/1992462

Mutluer D. and Barlas, Y. (2002). Modelling the Turkish Broad Money Demand, Central Bank Review 2 : 55-75.

Olgun, Hasan. (1982). Türkiye'de Ödemeler Dengesi, Para ve Enflasyon 1963-1976, Ankara: Orta Doğu Teknik Üniversitesi.

Payne James, E. (1992). Money Growth and Interest Rate Volatility and The Demand for Money, Journal of Economics and Finance 16 (1) : 103-114, doi: 10.1007/BF02919797, http://dx.doi.org//10.1007/BF02919797

Pesaran M. Hashem, Shin, Y. \& Smith, R. J. (2001). Bound Testing Approaches to the Analysis of Level Relationships, Journal of Applied Econometrics 16 : 289-326, doi:10.1002/jae.616, http://dx.doi.org//10.1002/jae.616 Sağlam Yıldız. (2005). Para Talep Teorileri ve Türkiye Uygulaması, yayınlanmamış doktora tezi, Ankara.

Sriram S. Subramanian. (1999(a)). Survey of Literature on Demand For Money:Theoretical and Empirical Work with Special Reference to Error Corerction Models, International Monetary Fund Working Paper 64:1-53.

Sriram S. Subramanian (1999(b)). Demand for M2 in an Emerging-Market Economy: An Error-Correction Model for Malaysia, International Monetary Fund Working Paper 173 : 1-49.

Sriram S. Subramanian. (2001). A Survey of Recent Empirical Money Demand Studies, IMF Staff Papers 47 (3) : 334-365.

Tobin, James. (1958). Liquidity Preference as Behavior Towards Risk, Review of Economic Studies 25 (67) : 65-86, doi: 10.2307/2296205, http://dx.doi.org//10.2307/2296205

Walsh, E.Carl. (1984). Interest Rate Volatility and Monetary Policy, Journal of Money, Credit and Banking 16 (2) : 133-150, doi: 10.2307/1992540, http://dx.doi.org//10.2307/1992540

\section{Notes}

Note 1. $\mathrm{IR}_{\mathrm{t}}=\ln \mathrm{V}_{\mathrm{t}} \ln r_{\mathrm{t}}$

Note 2. Consumer price index measures prices of a range of goods at retail outlets, while wholesale price index measures prices in a similar way at "factory gate", excluding some services and the impact of indirect taxes. The price deflators are obtained by dividing the current price measures by the constant price measure to give an index of prices relative to the base period (Lewis and Mizen, 2000: 265).

Note 3. For more details see Kamas, L. ve Joyce, J.P. (1993) Money, Income and Prices under Fixed Exchange Rates:Evidence from Causality Tests and VARs. Journal of Macroeconomics, 15 (4), 747-768.

Note 4. For example;

The long-run coefficient of Constant is calculated as follows:

$$
\frac{(-0.424264)}{1-[1.206365+(-0.287782)]}=-5.211000
$$

The long-run coefficient of GDP is calculated as follows:

$$
\frac{(0.169423)}{1-[1.206365+(-0.287782)]}=2.080929
$$

The long-run coefficient of RBSH is calculated as follows:

$$
\frac{(-0.011418+0.019242)}{1-[1.206365+(-0.287782)]}=0.096097
$$

The long-run coefficient of RMSH is calculated as follows:

$$
\frac{(-0.143107+0.094223)}{1-[1.206365+(-0.287782)]}=-0.600415
$$

The long-run coefficient of INF is calculated as follows: 


$$
\frac{(-0.558110+0.235315-0.077196)}{1-[1.206365+(-0.287782)]}=-4.912868
$$

The long-run coefficient of EXCH is calculated as follows:

$$
\frac{(0.264486-0.335275+0.0475518)}{1-[1.206365+(-0.287782)]}=-0.285409
$$

\begin{tabular}{|c|c|c|c|c|c|}
\hline VARIABLES & MODEL & $\begin{array}{l}\text { MACKINNNON CRITICICAL } \\
\text { VALUES ( } \% 1 \text { ve } \% 5 \text { ) }\end{array}$ & $\begin{array}{c}\text { ADF TEST } \\
\text { STATISTICS }\end{array}$ & LAG* & RESULT \\
\hline \multirow{4}{*}{$\mathrm{M} 2 \mathrm{Y}$} & $I^{* *}$ & $-2,593468,-1,944811$ & 5,059395 & {$[0]$} & $\mathrm{I}(1)$ \\
\hline & $\mathrm{II} * * *$ & $-3,512290,-2,897223$ & 0,170497 & {$[0]$} & $\mathrm{I}(1)$ \\
\hline & III $* * * *$ & $-4,073859,-3,465548$ & $-1,954194$ & {$[0]$} & $\mathrm{I}(1)$ \\
\hline & $\mathrm{IV}^{* * * * *}$ & $-2,593824,-1,944862$ & $-5,839664$ & {$[0]$} & $\mathrm{I}(1)$ \\
\hline \multirow{4}{*}{ GDP } & $I^{* *}$ & $-2,593468,-1,944811$ & 3.240966 & {$[0]$} & $\mathrm{I}(1)$ \\
\hline & $\mathrm{II} * * *$ & $-3.512290,-2.897223$ & -2.038551 & {$[0]$} & $\mathrm{I}(1)$ \\
\hline & $\mathrm{III} * * * *$ & $-4.075340,-3.466248$ & -2.760646 & {$[1]$} & $\mathrm{I}(1)$ \\
\hline & $\mathrm{IV}^{* * * * *}$ & $-2.593824,-1.944862$ & -7.054317 & {$[0]$} & $\mathrm{I}(1)$ \\
\hline \multirow{3}{*}{ RBSH } & $I^{* *}$ & $-2.593824,-1.944862$ & -3.221787 & {$[1]$} & $\mathrm{I}(0)$ \\
\hline & $\mathrm{II} * * *$ & $-3.512290,-2.897223$ & -7.319722 & {$[0]$} & $\mathrm{I}(0)$ \\
\hline & $\mathrm{III} * * * *$ & $-4.073859,-3.465548$ & -7.295437 & {$[0]$} & $\mathrm{I}(0)$ \\
\hline \multirow{4}{*}{ RMSH } & $I^{* *}$ & $-2.593468,-1.944811$ & -2.403780 & {$[0]$} & $\mathrm{I}(0)$ \\
\hline & $\mathrm{II} * * *$ & $-3.512290,-2.897223$ & -3.214398 & {$[0]$} & $\mathrm{I}(0)$ \\
\hline & $\mathrm{III} * * * *$ & $-4.073859,-3.465548$ & -3.261201 & {$[0]$} & $\mathrm{I}(0)$ \\
\hline & $\mathrm{IV}^{* * * * *}$ & $-2,594946,-1,945024$ & $-8,052676$ & {$[0]$} & $\mathrm{I}(1)$ \\
\hline \multirow{4}{*}{ INF } & $\mathrm{I}^{* *}$ & $-2.594189,-1.944915$ & -1.441980 & [1] & $\mathrm{I}(1)$ \\
\hline & $\mathrm{II} * * *$ & $-3.514426,-2.898145$ & -2.768178 & [1] & $\mathrm{I}(1)$ \\
\hline & $\mathrm{III} * * * *$ & $-4.075340,-3.466248$ & -5.683904 & {$[0]$} & $\mathrm{I}(1)$ \\
\hline & $\mathrm{IV}^{* * * * *}$ & $-2.594189,-1.944915$ & -14.25021 & {$[0]$} & $\mathrm{I}(1)$ \\
\hline \multirow{4}{*}{$\mathrm{EXCH}$} & $I^{* *}$ & $-2.593468,-1.944811$ & 0.216307 & {$[0]$} & $\mathrm{I}(1)$ \\
\hline & $\mathrm{II} * * *$ & $-3.512290,-2.897223$ & -0.697905 & {$[0]$} & $\mathrm{I}(1)$ \\
\hline & $\mathrm{III} * * * *$ & $-4.073859,-3.465548$ & -1.691873 & {$[0]$} & $\mathrm{I}(1)$ \\
\hline & $\mathrm{IV}^{* * * * * *}$ & $-2.593468,-1.944811$ & -6.254500 & {$[0]$} & $\mathrm{I}(1)$ \\
\hline
\end{tabular}

Table 1.The Results of ADF Unit Root Test

* Lag number of variables which are tested by using ADF test is determined by Schwarz Info Criterion (SIC)

**Model I, not include trend and intercept

***Model II, include intercept

****Model III, include intercept and trend

******Model which includes unit root test of differenced series

Table 2. Comparing F-statistics with critical values which are computed by Bound test

\begin{tabular}{|c|c|c|c|}
\hline \multirow{2}{*}{$\mathrm{k}$} & \multirow{2}{*}{ F statistics } & \multicolumn{2}{|c|}{ Critic values at \%5 significance level } \\
\cline { 3 - 4 } & & Lower Bound & Upper Bound \\
\hline 5 & 4.80 & 2.39 & 3.38 \\
\hline
\end{tabular}

Note: $\mathrm{k}$ is the number of independent variables that are taken in equation (4.4). Critical values are taken from the table CI, CI(ii) case which takes place in Pesaran, Shin and Smith (2001: 300). 
Table 3. The Results of ADRL $(2,0,1,1,2,2)$ Model and Long Term Coefficients

\begin{tabular}{|c|c|c|c|}
\hline Variables & Coefficients & t-statistics & Probabilities \\
\hline Constant & -0.424264 & $-2.867212 *$ & 0.0056 \\
\hline $\ln M 2 Y_{t-1}$ & 1.206365 & $10.08208^{*}$ & 0.0000 \\
\hline $\ln M 2 Y_{t-2}$ & -0.287782 & $-2.408776^{*}$ & 0.0188 \\
\hline $\operatorname{lnGDP}_{t}$ & 0.169423 & $3.043722 *$ & 0.0034 \\
\hline $\mathrm{RBSH}_{\mathrm{t}}$ & -0.011418 & -0.491291 & 0.6249 \\
\hline $\mathrm{RBSH}_{\mathrm{t}-1}$ & 0.019242 & 0.859730 & 0.3930 \\
\hline $\mathrm{RMSH}_{\mathrm{t}}$ & -0.143107 & $-1.809864 *$ & 0.0749 \\
\hline $\mathrm{RMSH}_{\mathrm{t}-1}$ & 0.094223 & 1.143977 & 0.2568 \\
\hline $\operatorname{lnINF}_{t}$ & -0.558110 & $-6.819095^{*}$ & 0.0000 \\
\hline $\operatorname{lnINF} F_{t-1}$ & 0.235315 & $2.157081^{*}$ & 0.0346 \\
\hline $\operatorname{lnINF}_{\mathrm{t}-2}$ & -0.077196 & -1.179815 & 0.2423 \\
\hline $\operatorname{lnEXCH} H_{t}$ & 0.264486 & 5.671986* & 0.0000 \\
\hline $\ln \mathrm{EXCH}_{\mathrm{t}-1}$ & -0.335275 & $2.157081 *$ & 0.0000 \\
\hline $\operatorname{lnEXCH}_{\mathrm{t}-2}$ & 0.0475518 & 0.798380 & 0.4275 \\
\hline \multicolumn{4}{|c|}{$R^{2}=0.998465 \bar{R}^{2}=0.998163 \quad F$ statistics $=3302.968$ Prob $(F$ statistics $): 0.000000 \quad D W$ statistics $=1.875208$} \\
\hline \multicolumn{4}{|c|}{ Long-Run Coefficients } \\
\hline Constant & \multicolumn{2}{|l|}{-5.211000} & \\
\hline GDP & \multicolumn{2}{|l|}{2.080929} & \\
\hline RBSH & \multicolumn{2}{|l|}{0.096097} & \\
\hline RMSH & \multicolumn{2}{|l|}{-0.600415} & \\
\hline INF & \multicolumn{2}{|l|}{-4.912868} & \\
\hline EXCH & \multicolumn{2}{|l|}{-0.285409} & \\
\hline
\end{tabular}

Note: The sign of * indicates the statistical significance at $5 \%$ level.

Table 4. The Results of Error Correction Model Based on ARDL $(2,0,1,1,2,2)$ Approach

\begin{tabular}{|c|c|c|c|}
\hline Variables & Coefficients & t-statistics & Probabilities \\
\hline Constant & 0.004407 & 0.975855 & 0.3328 \\
\hline $\operatorname{ECT}(-1)$ & -0.766013 & $-3.900930 *$ & 0.0002 \\
\hline$\Delta \ln M 2 Y_{\mathrm{t}-1}$ & 1.153232 & $6.665646^{*}$ & 0.0000 \\
\hline$\Delta \ln M 2 Y_{\mathrm{t}-2}$ & -0.321986 & $-2.532331 *$ & 0.0138 \\
\hline$\Delta \operatorname{lnGDP}{ }_{t}$ & 0.076585 & 0.665292 & 0.5083 \\
\hline$\Delta \mathrm{RBSH}_{\mathrm{t}}$ & -0.003140 & -0.169398 & 0.8660 \\
\hline$\Delta \mathrm{RBSH}_{\mathrm{t}-1}$ & 0.027848 & 1.514575 & 0.1348 \\
\hline$\Delta \mathrm{RMSH}_{\mathrm{t}}$ & -0.091983 & -1.156571 & 0.2517 \\
\hline$\Delta \mathrm{RMSH}_{\mathrm{t}-1}$ & 0.006833 & 0.089036 & 0.9293 \\
\hline$\Delta \operatorname{lnINF}_{t}$ & -0.584367 & $-6.215791 *$ & 0.0000 \\
\hline$\Delta \operatorname{lnINF} F_{t-1}$ & 0.230649 & $1.872685^{*}$ & 0.0657 \\
\hline$\Delta \operatorname{lnINF_{t-2}}$ & -0.099900 & -1.516659 & 0.1343 \\
\hline$\Delta \ln \mathrm{EXCH}_{\mathrm{t}}$ & 0.206712 & $4.481017 *$ & 0.0000 \\
\hline$\Delta \ln \mathrm{EXCH}_{\mathrm{t}-1}$ & -0.300461 & $-4.993084 *$ & 0.0000 \\
\hline$\Delta \ln \mathrm{EXCH}_{\mathrm{t}-2}$ & 0.008207 & 0.137799 & 0.8908 \\
\hline
\end{tabular}

Note: The sign of * indicates the statistical significance at $5 \%$ level. 